\title{
Distribution and Abundance of Freshwater Mussels in the mid Klamath Subbasin, California
}

Author(s): Emily A. Davis , Aaron T. David , Kari Marie Norgaard, Timothy H. Parker, Kara McKay , Christine Tennant , Toz Soto , Kate Rowe , and Ronald Reed

Source: Northwest Science, 87(3):189-206. 2013.

Published By: Northwest Scientific Association

DOI: http://dx.doi.org/10.3955/046.087.0303

URL: http://www.bioone.org/doi/full/10.3955/046.087.0303

BioOne (www.bioone.org) is a nonprofit, online aggregation of core research in the biological, ecological, and environmental sciences. BioOne provides a sustainable online platform for over 170 journals and books published by nonprofit societies, associations, museums, institutions, and presses.

Your use of this PDF, the BioOne Web site, and all posted and associated content indicates your acceptance of BioOne's Terms of Use, available at www.bioone.org/page/terms_of_use.

Usage of BioOne content is strictly limited to personal, educational, and non-commercial use. Commercial inquiries or rights and permissions requests should be directed to the individual publisher as copyright holder. 
Emily A. Davis*1, University of Washington, School of Aquatic and Fishery Sciences, Box 355020, Seattle, WA 98195

Aaron T. David*, University of Washington, School of Aquatic and Fishery Sciences, Box 355020, Seattle, WA 98195

Kari Marie Norgaard, Departments of Sociology and Environmental Studies, University of Oregon, Eugene, OR 97403

Timothy H. Parker, Department of Biology, Whitman College, Walla Walla, WA 99362

Kara McKay, Department of Biology, Whitman College, Walla Walla, WA 99362

Christine Tennant, Department of Biology, Whitman College, Walla Walla, WA 99362

Toz Soto, Department of Natural Resources, Karuk Tribe, 39051 Hwy 96, Orleans, CA 95556

Kate Rowe, Salmon River Restoration Council, Sawyers Bar, CA 96027

and

Ronald Reed, Department of Natural Resources, Karuk Tribe, 39051 Hwy 96, Orleans, CA 95556

\title{
Distribution and Abundance of Freshwater Mussels in the mid Klamath Subbasin, California
}

\begin{abstract}
Freshwater mussels (Bivalvia: Unionoida) are an integral component of freshwater ecosystems. Historically, they were an important part of the diet and material culture of indigenous peoples, including until recently the Karuk Tribe of California. This study represents the first systematic survey of freshwater mussels in the Klamath River Basin of northwestern California, where little is known about mussel distribution, abundance, habitat associations, or conservation status. We snorkel surveyed 82 sites on the mid Klamath River and sections of nine major tributaries to assess abundance, distribution, and habitat use of mussels at three different spatial scales. We identified all three western North American mussel genera (Margaritifera, Gonidea, and Anodonta) in the Klamath River, with Gonidea abundant and widely distributed within the mainstem, and Anodonta and Margaritifera present in low numbers and restricted in distribution. At the landscape scale we observed a negative relationship between mussel abundance and measures of hydrological variability. At the mesohabitat scale, bank type, channel unit type, and their interaction were important predictors of mussel distribution. At the microhabitat scale, bank type, substrate type, and flow refuge presence were important predictors of mussel distribution. Together, our results suggest the common influence of hydraulics and substrate stability as drivers of mussel distribution in the Klamath, which agrees with the findings of other recent studies of mussel distribution. Our results also illuminate where habitat protection and restoration efforts should be directed within the mid Klamath subbasin to aid in mussel conservation.
\end{abstract}

Key Words: freshwater mussels; Klamath River; Karuk Tribe; habitat distribution; mixed effects models

\section{Introduction}

Freshwater mussels (Bivalvia: Unionoida) face significant conservation challenges. In North America alone, over 70 percent of the estimated 300 species are either extinct or at risk of extinction (Williams et al. 1993, Neves et al. 1997). Declines of freshwater mussels are of concern in part because mussels provide valuable ecosystem services such as substrate aeration, nutrient depo-

\footnotetext{
${ }^{1}$ Author to whom correspondence should be addressed. Email: davisem@uw.edu.

*Equal contribution by both authors.
}

sition, and water filtration within rivers and lakes (Vaughn and Hakenkamp 2001, Vaughn et al. 2004, Howard and Cuffey 2006). In many regions, the ability to manage and conserve mussel populations is hampered by limited knowledge of species distributions and habitat associations (Brim Box et al. 2006). Describing the presence, distribution, and habitat needs of freshwater mussel species is a necessary first step to protecting populations.

Western North America is home to far fewer genera (3) and species (6-8) of mussels than are watersheds east of the Rockies where most of the North American diversity is located. There are few 
comprehensive surveys and little basic knowledge of ecology, taxonomy, or zoogeography of mussels in the western United States (Brim Box et al. 2006). However, based on recent survey efforts, we know that some western mussels, including Gonidea angulata and one or more species of Anodonta, have likely been extirpated from parts of their former ranges (Nedeau et al. 2009, Howard 2010).

Despite intensive anthropogenic use of freshwater ecosystems in California, little is known about the conservation status or ecology of mussels in California. According to a recent synthesis of historical observations, all three genera of western mussels, Gonidea, Margaritifera and Anodonta, appear to be in decline statewide, with some populations completely extirpated (Howard 2010). The Klamath River Basin in Northern California is one example of a major western river basin where little is known about the distribution or ecology of freshwater mussels. Thirty isolated samples dating from between 1867 and the present day are recorded in the US Forest Service's Database of Freshwater Mollusks of the Western United States (USDA Forest Service 2004). However, to our knowledge, there had been no detailed, systematic study of mussels in the Klamath River prior to our work.

Besides their importance in aquatic ecosystems, freshwater mussels are also culturally significant. Historically, mussels formed an important part of the diet and material culture of indigenous peoples in North America (Parmalee and Klippel 1974), including, until the 1960s and 1970s, members of the Karuk Tribe of California (Kroeber and Barrett 1960, Ferrara 2004), whose homeland encompasses the middle Klamath Basin. Ethnographic accounts document Karuk use of freshwater mussels (axthah in the Karuk language) as food, tools, and game pieces (Gibbs 1860, Driver 1939, Greengo 1952). The cultural importance of mussels, coupled with their role in aquatic ecosystems and unknown conservation status, underscored the importance of initiating this study.

Inadequate knowledge of mussel habitat requirements and the factors that determine or constrain mussel distribution hinders mussel con- servation (Strayer 2008). Mussel populations and the environments they inhabit are heterogeneous and fragmented (Newton et al. 2008), leading some researchers to suggest that principles of landscape ecology, including consideration of influences operating on multiple spatial scales, should be used to understand and manage populations (Newton et al. 2008).

There have been attempts to explain the patchy, aggregated distribution of mussel species at mesohabitat $(10 \mathrm{~m}-100 \mathrm{~m})$ and microhabitat $(<10 \mathrm{~m})$ scales (Strayer 2008) using traditional microhabitat-scale variables such as water velocity and water depth, but those variables have been found to be poor predictors of mussel distribution (Strayer and Ralley 1993). More recently, complex hydraulic variables (shear stress, Reynolds and Froude's numbers) have emerged as better predictors and descriptors of mussel distribution, abundance, and patch suitability at meso and micro scales (McRae et al. 2004, Strayer 2008, Zigler et al. 2008). Hydraulic conditions at micro and meso scales can influence substrate stability, bed scour, presence of flow refuges (micro-eddies), and other variables relevant to benthic-dwelling organisms.

Mussel presence is also patchy at the landscape scale ( $>100 \mathrm{~m}$ to many $\mathrm{km})$, which can be attributed to a variety of factors such as host fish distribution, geology, climate, and land use (Arbuckle and Downing 2000, McRae et al. 2004, Vaughn and Taylor 2000). Some research has also shown that landscape-scale differences in mussel communities and distribution correspond with areas of differing hydrological variability. Hydrological variability can influence the presence or absence of certain substrates, the degree of siltation, the amount of scouring experienced at a site, and the presence or absence of host fish, all of which can in turn influence mussels (diMaio and Corkum 1995).

Our primary objectives were to: 1) identify mussel species of the middle Klamath River and its major tributaries, 2) quantify the relative abundance of these species, and 3) assess their distribution throughout the 250 river $\mathrm{km}$ of the study area. Our secondary objective was to investigate mussel habitat associations at macro (landscape, $>100 \mathrm{~m}$ to many $\mathrm{km}$ ), meso (reach, $10 \mathrm{~m}-100 \mathrm{~m}$ ) and 
micro (local, $<10 \mathrm{~m}$ ) scales. We examined mussel distribution at multiple spatial scales because research indicates that biotic and abiotic factors at different scales can interact with each other to produce a complicated suite of patterns (McRae et al. 2004). Accordingly, we investigated the influence of hydrological variability (macro scale), bank type and channel unit type (meso scale), and substrate type and flow refuges (micro scale) on the distribution and abundance of mussels.

\section{Methods}

\section{Study Area}

The Klamath River, located in northwestern California and southern Oregon (Figure 1), is the second-largest river basin in California, draining an area of 40,632 $\mathrm{km}^{2}$. The Klamath Basin is an unusual watershed, with an expansive alluvial and lacustrine upper basin transitioning to a steep, confined, erosive mountain river system in the lower basin - the opposite of many river systems (NRC 2004, VanderKooi et al. 2011). The boundary between upper and lower basins is generally defined based on the underlying geology (Williams and Curry 2011). The upper basin is semi-arid and primarily vegetated by shrubs, grasses, and ponderosa pine (Pinus ponderosa); the lower basin is more mesic and primarily vegetated by mixed conifer-hardwood forest. The dominant land use in the upper basin is agriculture, whereas the majority of land in the lower basin is forest managed by the US Forest Service and the Yurok and Hoopa Indian tribes.

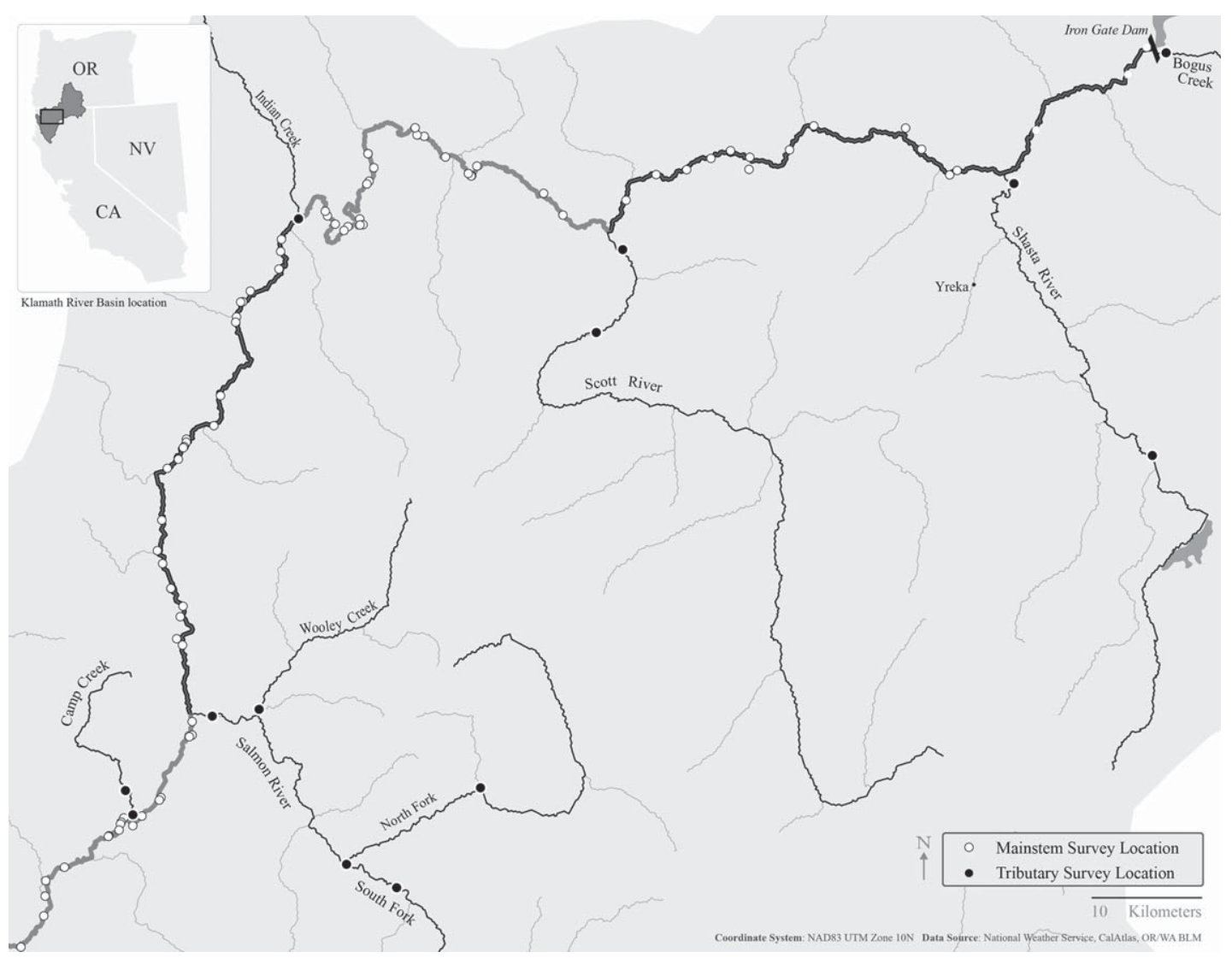

Figure 1. The middle Klamath basin with the mainstem study sections denoted with alternating gray and black lines. From upstream to downstream the sections are Irongate Dam-Scott River, Scott River-Indian Creek, Indian Creek-Salmon River, and Salmon River-Trinity River. Mainstem survey sites are identified as white points, and tributary surveys as dark points. The tributaries we surveyed are labeled and identified with darkened lines. 
Four hydroelectric dams block the mainstem Klamath as it transitions from the upper to the lower basin. During summer, warm, nutrient-rich water from the upper basin is trapped behind the dams, promoting blooms of the hepatotoxic blue-green algae Microcystis aeruginosa (Kann 2006). Water quality improves downstream as the influence of major tributaries reduces nutrient and toxin concentrations (Asarian et al. 2010) and increases dissolved oxygen concentrations (Karuk Tribe 2008). The dams also alter the hydrologic regime, sediment transport, and the movement of aquatic animals (the dams lack fish ladders). Discharge from the lowermost dam, Irongate, is normally between 1,000 and 2,000 $\mathrm{cf} \mathrm{s}^{-1}$ (Williams and Curry 2011).

Our study area was the middle Klamath basinthe upper two thirds of the lower basin — between Irongate Dam and the Trinity River confluence (Figure 1). Much of this area overlaps Karuk ancestral territory. The geomorphic, climatic, and hydrologic character of the watershed changes dramatically between the upper and lower basins (Williams and Curry 2011), but also changes substantially within the study area itself. Differences in hydrological variability have been shown to influence the distribution and abundance of species such as juvenile coho salmon (Oncorhynchus kisutch) in the Klamath River (Hillemeier et al. 2009), and may influence patterns of mussel distribution. For this reason, we divided the 250 river $\mathrm{km}$ of our study area into four sub-sections with differing hydrologic regimes (Figure 1).
The furthest upriver section of the study area, between Irongate Dam and the Scott River, is characterized by a semi-arid climate, regulated flows year round, and a virtual absence of yearly peak flow events (Hillemeier et al. 2009). Moving downstream, the size and frequency of peak flow events, along with overall hydrological variability, all increase as the climate becomes more mesic, more tributaries enter the Klamath, and the system shifts from being dominated by groundwater and snowmelt to rain and snowmelt (Hillemeier et al. 2009). From upriver to downriver, the other three study area sections comprise the reaches between the Scott River and Indian Creek, between Indian Creek and the Salmon River, and between the Salmon River and the Trinity River (Figure 1).

\section{Site Selection}

We used a previous habitat survey of the Klamath River (USFWS 2002) to select survey sites and to evaluate the influence of channel unit type (i.e., channel geomorphology) on mussel distribution. The habitat survey divided the river into sequential channel units from Irongate Dam to the ocean, specified the length and georeferenced position of each unit and categorized these units as one of five types: low slope (LS), medium slope (MS), steep slope (SS), riffle, pool, or run. The channel unit types were defined using a series of habitat characteristics: gradient, active-channel confinement, surface disturbance, width to depth ratio, substrate composition, and the presence or absence of backwaters associated with hydraulic controls (Hendrix et al. 2011) (Table 1). This categorization

TABLE 1. Characteristics used to define channel unit types in a 2002 USFWS habitat survey of the Klamath River from Irongate Dam to the estuary. Adapted from table 4.3 in Hendrix et al. (2011). LS = low slope; MS = medium slope; $\mathrm{SS}=$ steep slope.

\begin{tabular}{llllll}
\hline Criteria & Pool & Run & LS Riffle & MS Riffle & SS Riffle \\
\hline Gradient & -- & $<0.3 \%$ & $<0.3 \%$ & $0.3 \%-0.8 \%$ & $>0.8 \%$ \\
Channel width & -- & confined & $\begin{array}{l}\text { relatively } \\
\text { unconfined }\end{array}$ & $\begin{array}{l}\text { moderately } \\
\text { confined }\end{array}$ & confined \\
Backwater & yes & no & no & no & no \\
Substrate & fines, sand, & -- & gravel, & large cobble, & small and \\
& gravel & & small cobble & small boulder & large boulder \\
Standing waves & none & $<1 / 2^{\prime}$ & $<1 / 2^{\prime}$ & $1 / 2^{\prime}-1^{\prime}$ & $>1^{\prime}$ \\
\hline
\end{tabular}


is similar to the stream channel unit classification system of Hawkins et al. (1993). From this dataset we used a random number generator to select channel units between Irongate Dam and the Klamath-Trinity confluence as our survey sites. We replaced units that were unsafe or inaccessible with nearby units of the same type.

We did not select tributary sites randomly, as habitat mapping similar to the survey of the mainstem was not available for tributaries. We opportunistically selected sites using the goals of broad spatial coverage of the middle basin, site accessibility and safety, and anecdotal reports of mussel presence. From upriver to downriver along the Klamath we surveyed sites on Bogus Creek, the Shasta River, the Scott River, Indian Creek, the Salmon River (mainstem, North Fork, and South Fork), Wooley Creek (a tributary of the Salmon River), and Camp Creek.

We surveyed a total of 82 sites on the mainstem Klamath River and 19 sites on Klamath tributaries during the summers of 2007, 2009, and 2010. We also conducted within-season resurveys of 5 sites in 2009 and 10 sites in 2010 to assess the precision of our mussel counts.

\section{Surveys}

We defined a mainstem site as a $50 \mathrm{~m}$ segment of river within a single channel unit. Individual units could be hundreds of meters in length, making whole-unit surveys impractical. A $50 \mathrm{~m}$ length of channel struck a balance between accurately representing the larger channel unit and the timeintensive nature of the surveys. Once we arrived at a pre-selected channel unit and delineated the site within the unit, we systematically surveyed the site, covering as much riverbed as possible. One or more surveyors snorkeled each side of the river, moving parallel to the bank. We snorkeled as far out into the middle of the river as possible, but swift currents often prevented a detailed midchannel survey. However, cursory surveys (e.g., while swimming across the main channel to the other bank) showed that the mid-channel held few if any mussels.

At each site we recorded the species present and the total number of individuals per spe- cies. We counted only mussels visible on the surface of the river bed and did not excavate the substrate. Mussels were identified on the basis of shell morphology. Surveyors noted the side of the main channel (right or left) where each mussel or mussel bed occurred and recorded the bank type of both sides of the river at each site. The two bank types we used, bar edge and bank edge, were adapted from Beechie et al. (2005). Bar edges sloped gradually to the water's edge and consisted of loose, deposited cobble, gravel, or sand. Bank edges sloped steeply to the water's edge and consisted of stable, embedded boulders, bedrock, mud or other hardened substrate. Bank type is indicative of the hydrologic influence on the channel edge, such as the level of shear stress during peak flow events, whether scour or deposition dominates, and the stability of the substrate.

Any large, dense aggregation of mussels where it was not practical to count all individuals we defined as a "bed" and sampled with a $0.25 \mathrm{~m}^{2}$ quadrat using an adaptation of systematic sampling (Strayer and Smith 2003). First, we determined the area of the bed to calculate how many quadrats would be needed to sample at least $10 \%$ of the total bed area. We then placed the quadrat at regular intervals along one or more linear transects within the bed, identifying and counting all mussels in each quadrat. Later we estimated the total number of mussels in the bed by extrapolation.

In 2010 we surveyed two new mainstem sites and resurveyed 19 sites previously surveyed in 2007 or 2009 to assess the effect of two microhabitat variables, substrate and flow refuges, on mussel distribution. We used substrate type and presence of flow refuges, as well as bank type and channel unit type, as proxies for local hydraulic conditions and substrate stability. We were unable to observe these variables directly since most of the limiting hydraulic conditions for mussels occur during winter flooding, rather than summer low flows when we completed our surveys. We recorded the substrate occupied by each mussel and whether or not a mussel was associated with a flow refuge. For mussel beds we recorded the dominant substrate within each quadrat and whether or not that quadrat was associated with 
a flow refuge. We used six substrate categories: bedrock, boulder (>256 mm), cobble $(64-256 \mathrm{~mm})$, gravel (2-63 mm), sand (0.125-1.9 mm), and silt. We defined a flow refuge (Strayer 1999) as the area immediately downstream of any physical element, such as a boulder, large cobble, or bedrock outcropping, which slowed or deflected the current's downstream flow, creating a micro-eddy.

At each site we also recorded the availability of substrate types and potential flow refuges. We sampled the substrate at a series of 30-40 points spaced evenly throughout the site. Surveyors placed the end of a pole on the river bottom at each point, recording the substrate that the pole touched and whether a physical bed element created a potential flow refuge at that point.

For the tributary surveys we focused only on the presence and abundance of mussel species, and did not assess habitat associations. In contrast to the mainstem surveys, tributary survey sites varied in length, often up to hundreds of meters. Some tributaries contained more than one site. We surveyed all tributaries in teams of at least three, with each person surveying a third of the channel. We identified and counted all mussels encountered, standardizing our counts as the number of mussels per $50 \mathrm{~m}$ of stream channel to make them comparable with our mainstem surveys.

For the four mainstem sections defined at the outset of the study (Irongate Dam-Scott River, Scott River-Indian Creek, Indian Creek-Salmon River, Salmon River-Trinity River) we calculated two measures of hydrological variability: highto-low flow ratio and coefficient of variation $\left(C_{v}\right)$ among daily mean flows, using flow data from the whole period of record for the gauges located within each of the sections (USGS 2011). We also calculated these measures for surveyed tributaries with gauges on them (four of nine). Coefficient of variation is a standard measure of hydrological variability that has been shown to influence aquatic communities (Jowett and Duncan 1990), and both $C_{v}$ and high- to-low flow ratio influence the distribution of juvenile coho salmon (O. kisutch) in the Klamath River (Hillemeier et al. 2009). The high- to-low flow ratio is the ratio of the median annual peak flow to the median annual low flow. Coefficient of variation $\left(C_{v}\right)$ is defined as

$$
C_{v}=\frac{S D_{d f}}{\overline{d f}} * 100
$$

where $S D_{d f}$ is the standard deviation of daily mean river flow, and $\overline{d f}$ is the mean of daily mean flow.

No gauge exists for the Indian Creek - Salmon River section of the Klamath. To calculate measures of hydrologic variability for this section we combined the daily mean flows from the closest upriver mainstem gauge and from Indian Creek.

\section{Data Analysis}

We used the two surveys from each of the resurveyed sites to calculate the precision (i.e., intraclass correlation) (Lessells and Boag 1987) of our counts of each species we encountered at those sites and our substrate coverage sampling. We assessed the relationship between the combined counts of all mussel species at each site $\left(\log _{e}\right.$ +1 transformed), the distance downstream of Irongate Dam, and both measures of hydrological variability using linear regression. Adequacy of the fit of the hydrological variability regression models was assessed using analysis of variance. We also assessed the relationship between mussel counts (mussels per $50 \mathrm{~m}$ of channel length; $\log _{\mathrm{e}}$ +1 transformed) and hydrological variability in the four gauged tributaries using linear regression. The criterion of $P \leq 0.10$ was used as the significance cutoff for all statistical tests.

We evaluated the relationship between mussel counts and meso and microhabitat variables using a series of generalized linear mixed models (GLMM) (reviewed by Bolker et al. 2009). We used the GLMM framework because it handles non-normal response variables and can account for nested, non-independent sampling. For all models we used a negative binomial error distribution (log link) because mussel counts were not normally distributed, and we included site as a random effect to account for the non-independence of counts within a site. We fit the models in R (R Development Core Team 2011) using the glmmadmb function in the glmmADMB package (Skaug et al. 2012). The glmmadmb function fits models 
using a Laplace approximation of maximum likelihood estimation. Because Margaritifera falcata and Anodonta sp. had restricted distributions (see results) we performed these analyses for $G$. angulata counts only.

We considered two separate sets of models. Our first set of models evaluated mussel abundance at the mesohabitat scale using meso-scale explanatory variables. We constructed four models with different combinations of meso-scale variables that represented alternate hypotheses about which variables could be important to mussel abundance at this scale. The level of observation for the mesoscale models was the side of a site (i.e., the left or right half of a $50 \mathrm{~m}$ section of channel). For these models we used data from sites surveyed in 2007 and 2009, plus the two sites surveyed in 2010 that were not previously surveyed in 2007 or 2009. We included the explanatory variables channel unit type (Pool, LS riffle, MS riffle, and SS riffle), bank type (bank edge and bar edge), and the interaction between channel unit type and bank type as fixed effects in these models.

Our second set of models evaluated mussel abundance at the microhabitat scale using both meso- and micro-scale explanatory variables. We constructed 17 separate models with different combinations of meso- and micro-scale variables that represented alternate hypotheses about which variables could be important to mussel abundance at the microhabitat scale. The level of observation for the micro-scale models was individual substrate and flow refuge categories within each side of a site. For example, mussels counted in gravel associated with flow refuges on the left side of a site would be a single observation. For these models we used data from sites sampled in 2010 as these were the only sites where we collected microhabitat information. We included the explanatory variables channel unit type (Pool, LS riffle, and MS riffle), bank type, substrate (bedrock, boulder, cobble, gravel, sand, and silt), flow refuge presence/absence, the interaction between channel unit type and bank type, the interaction between substrate and flow refuge presence/absence, and the interaction between bank type and flow refuge presence/absence as fixed effects in these models. For models that included substrate and flow refuge presence/absence as explanatory variables we included substrate-flow refuge coverage (the percent cover by a given substrate associated with and without flow refuges as determined by point intercept sampling on a given side of the site in question) as a covariate to account for differential availability of substrates and flow refuges among sites. We only evaluated models that seemed biologically relevant and interpretable, as opposed to evaluating every possible combination of explanatory variables, to reduce the probability of finding spurious effects (Anderson and Burnham 2002).

To determine which variables or sets of variables were most important in explaining mussel abundance we used an information-theoretic (IT) model selection approach (Anderson et al. 2000). The IT approach provides an alternative to traditional null-hypothesis based inference, which suffers from drawbacks when used with GLMMs (Bolker et al. 2009). We compared models using the Akaike information criterion with a bias correction term for small sample size $\left(\mathrm{AIC}_{\mathrm{c}}\right)$ and $\mathrm{AIC}_{\mathrm{c}}$ weights. For each model we report $\mathrm{AIC}_{\mathrm{c}}$ for $\operatorname{model}_{i}-\operatorname{AIC}_{\mathrm{c}} \min \left(\Delta_{i}\right)$ and the $\mathrm{AIC}_{\mathrm{c}}$ weight for $\operatorname{model}_{i}\left(w_{i}\right)$. We also report the model summaries for the best model ( $\mathrm{AIC}_{\mathrm{c}} \mathrm{min}$ ) for both the meso-scale and micro-scale models.

\section{Results}

\section{Survey Precision}

Our counts of $G$. angulata in 2009 were significantly precise $(\mathrm{r}=0.92, F=22.77, \mathrm{df}=4,5, P=$ 0.002). Counts of $M$. falcata, by contrast, showed poor precision $(\mathrm{r}=0.31, F=1.92, \mathrm{df}=4,5, P=$ 0.246). In 2010 our counts of $G$. angulata and $M$. falcata were significantly precise within substrateflow refuge categories at each site $(\mathrm{r}=0.66, F=$ 4.85, $\mathrm{df}=239,240, P<0.0001 ; \mathrm{r}=0.46, F=$ $2.69, \mathrm{df}=239,240, P<0.0001$, respectively). Substrate coverage estimated from point-intercept sampling was also significantly precise $(\mathrm{r}=0.67$, $F=5.12, \mathrm{df}=239,240, P<0.0001)$.

\section{Large-Scale Patterns of Distribution and Abundance}

We identified all three genera of western mussels in the mid Klamath River. We were able to identify 
TABLE 2. The number of survey sites in each section and mean (SD) species abundance per site for each of the four mainstem Klamath sections. The bottom row shows the total number of each species counted at all survey sites.

\begin{tabular}{lcccc}
\hline Mainstem Section & $\mathrm{n}$ & \multicolumn{3}{c}{ Mean (SD) } \\
\hline & & $\underline{\text { G. angulata }}$ & $\underline{\text { M. falcata }}$ & $\underline{\text { Anodonta sp. }}$ \\
Irongate-Scott River & 16 & $4192(6859)$ & $1(3)$ & $95(358)$ \\
Scott River-Indian Creek & 23 & $3838(6322)$ & $5(11)$ & $0(0)$ \\
Indian Creek-Salmon River & 25 & $1110(2253)$ & $2(5)$ & $0(0)$ \\
Salmon River-Trinity River & 18 & $796(2408)$ & $95(253)$ & $0(0)$ \\
Total & 82 & 197418 & 1879 & 1515 \\
\hline
\end{tabular}

G. angulata and M. falcata to the species level using shell morphology. However, western anodontines make up three distinct clades which are difficult to distinguish without a genetic analysis (Chong et al. 2008, Mock et al. 2010), so we were unable to assign the Anodonta specimens to a species or clade.

Mussels were abundant (Table 2) and widely distributed throughout the mainstem Klamath (Figure 2), though abundance varied widely among sites. We found mussels at 70 of 82 sites. G. angulata were more widely distributed (Figure 2) and more abundant than the other species by two orders of magnitude (Table 2). In contrast to G. an- gulata, 95 percent of all Anodonta sp. we counted in this survey were located at the furthest upriver survey site-directly below Irongate Dam. During formal distribution surveys, we only observed Anodonta sp. in the furthest upriver mainstem section (Irongate Dam - Scott River) (Figure 2; Table 2); however, during an exploratory survey we did identify a few Anodonta sp. just upstream of a survey site located approximately 105 river $\mathrm{km}$ below the dam. We observed the opposite distribution for M. falcata, with low abundances in the upper three mainstem sections and the highest abundances in the furthest downstream section of the study area, between the Salmon

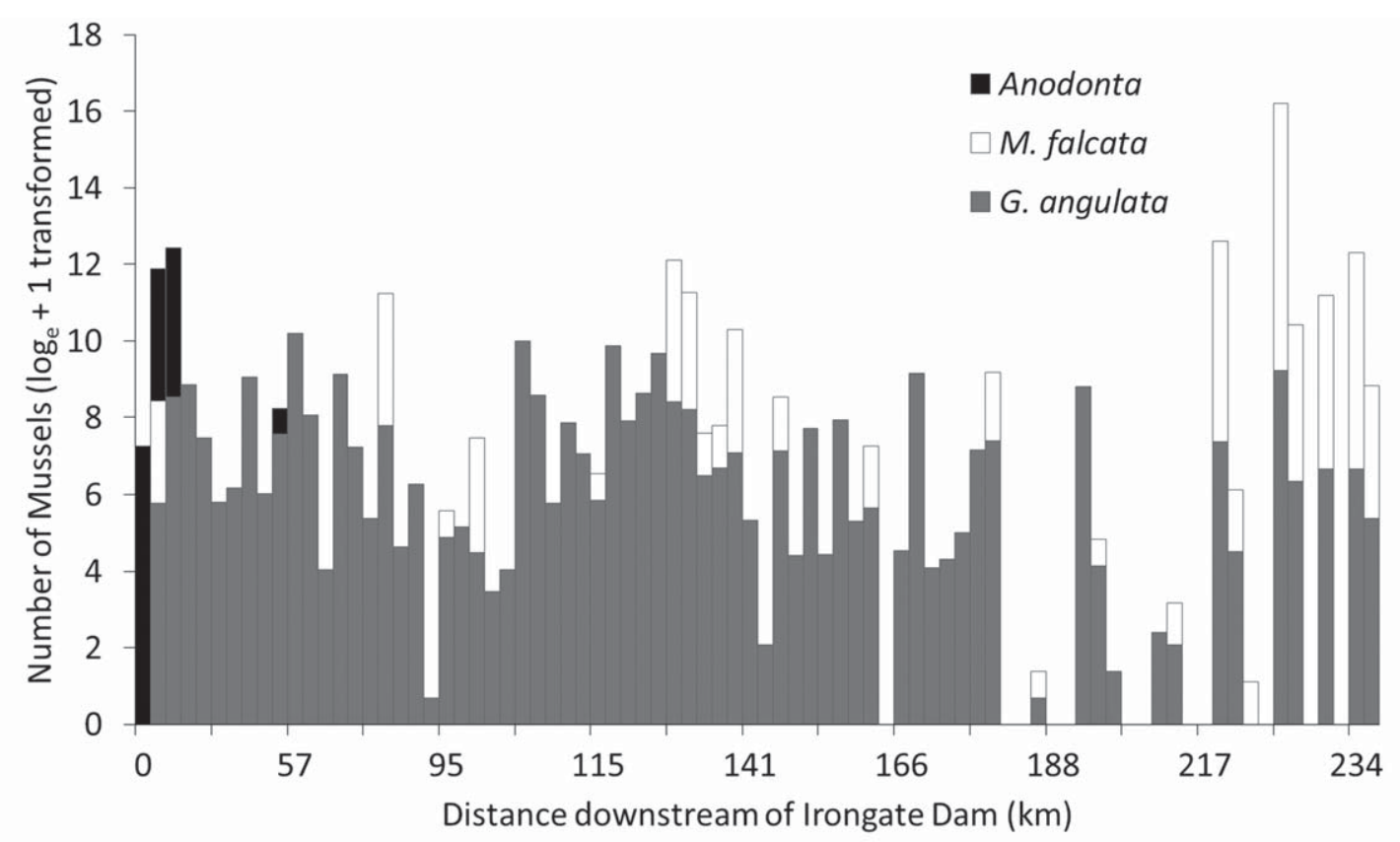

Figure 2. Longitudinal distribution of Klamath mainstem mussel abundance $\left(\log _{\mathrm{e}}+1\right.$ transformed). 
TABLE 3. Measures of hydrological variability for the four mainstem river sections and four gauged mid Klamath tributaries, plus the length of each of the four mainstem sections $(\mathrm{km})$ and the distance surveyed on each mainstem section and tributary ${ }^{1}$. The high- to-low flow ratio is the ratio of the median annual peak flow to the median annual low flow. Coefficient of variation $\left(C_{\mathrm{v}}\right)$ is the ratio of the standard deviation of daily mean river flow to the mean of daily mean river flow and is represented as a percentage. The length of the period of record (years) used for each calculation is noted.

\begin{tabular}{lcccrc}
\hline Mainstem section/tributary* & $\begin{array}{c}\text { Length } \\
(\mathrm{km})\end{array}$ & $\begin{array}{c}\text { Distance } \\
\text { surveyed }(\mathrm{m})\end{array}$ & $\begin{array}{c}\text { High-low } \\
\text { flow ratio }\end{array}$ & \multicolumn{1}{c}{$C_{v}$} & $\begin{array}{c}\text { Years of } \\
\text { record }\end{array}$ \\
\hline Irongate-Scott River & 77 & 800 & 8.4 & $83.7 \%$ & 52 \\
Scott River-Indian Creek & 59.25 & 1150 & 17.0 & $101.0 \%$ & 100 \\
Indian Creek-Salmon River & 67 & 1250 & 23.5 & $111.8 \%$ & 56 \\
Salmon River-Trinity River & 37 & 900 & 38.2 & $122.7 \%$ & 84 \\
Shasta River* & & 1700 & 103.3 & $128.0 \%$ & 78 \\
Scott River* & & 1500 & 175.1 & $167.8 \%$ & 71 \\
Indian Creek* & & 2600 & 162.9 & $162.4 \%$ & 56 \\
Salmon River* & & 134.7 & $140.7 \%$ & 101 \\
\hline
\end{tabular}

${ }^{1}$ Ungauged, surveyed tributaries and distance (m) surveyed: Bogus Creek (350), N. Fork Salmon (3000), S. Fork Salmon (3000), Wooley Creek (1000), and Camp Creek (1600).

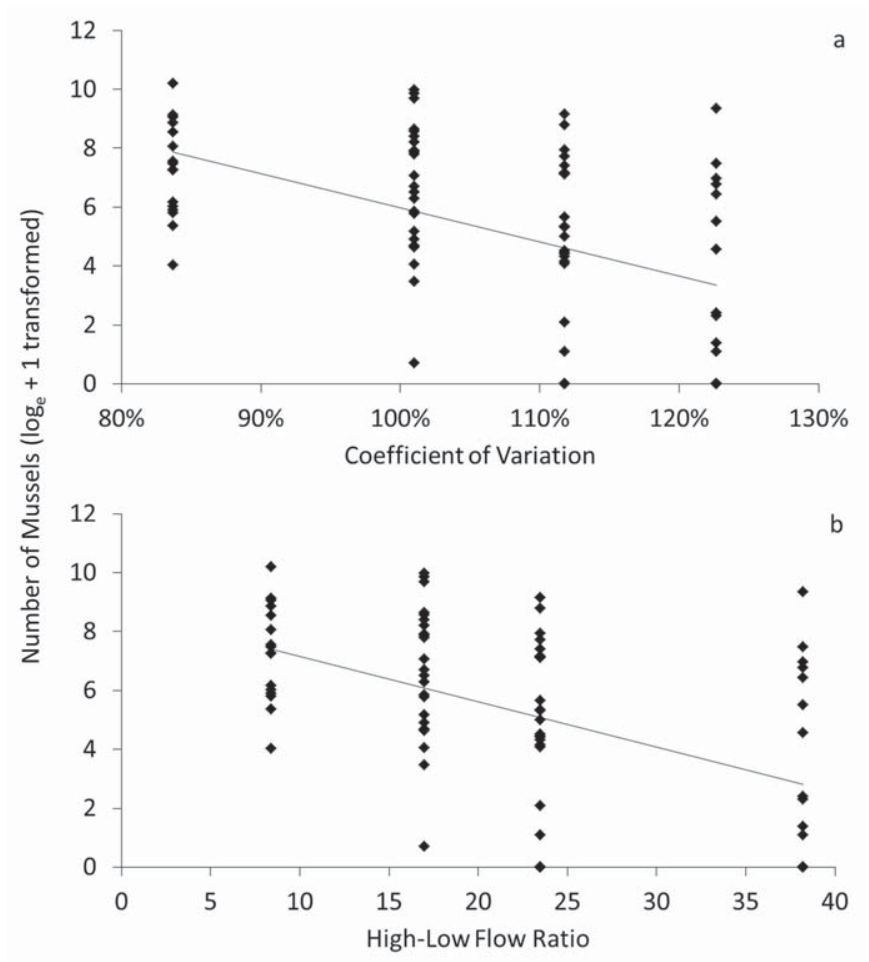

Figure 3. The relationship between two measures of hydrological variability in the mainstem Klamath River and the site counts of all mussel species combined ( $\log _{\mathrm{e}}+1$ transformed). (a) Coefficient of variation. (b) High-low flow ratio. and Trinity Rivers (Figure 2; Table 2). Where M. falcata was present, it co-occurred with $G$. angulata at all but one site. Anodonta sp. co-occurred with $G$. angulata at two sites and with M. falcata at a single site. G. angulata was the only species found at 44 sites, while M. falcata and Anodonta sp. were each found alone at a single site.

Mussels declined in abundance with increasing distance downstream of Irongate Dam $\left(\mathrm{r}^{2}=0.24, F=24.66\right.$, $\mathrm{df}=1,80, P<0.001)$ (Figure 2). Both measures of hydrological variability, the high-to-low flow ratio and $C_{v}$, increased with increasing downstream distance from Irongate Dam (Table 3). We found a negative relationship between both measures of hydrological variability and the site counts of total mussels $\left(C_{v}: \mathrm{r}^{2}=0.25, F=26.97, \mathrm{df}=1,80\right.$, $P<0.001$; High-Low: $\mathrm{r}^{2}=0.26, F=$ 27.96, df $=1,80, P<0.001$ ) (Figure $3 \mathrm{a}, 3 \mathrm{~b}$ ). Both linear models of hydrological variability and mussel counts adequately fit the data $\left(C_{v}: F=1.51\right.$, $\mathrm{df}=2,78, P=0.227$; High-Low: $F=$ 1.14 , df $=2,78, P=0.326$ ). 


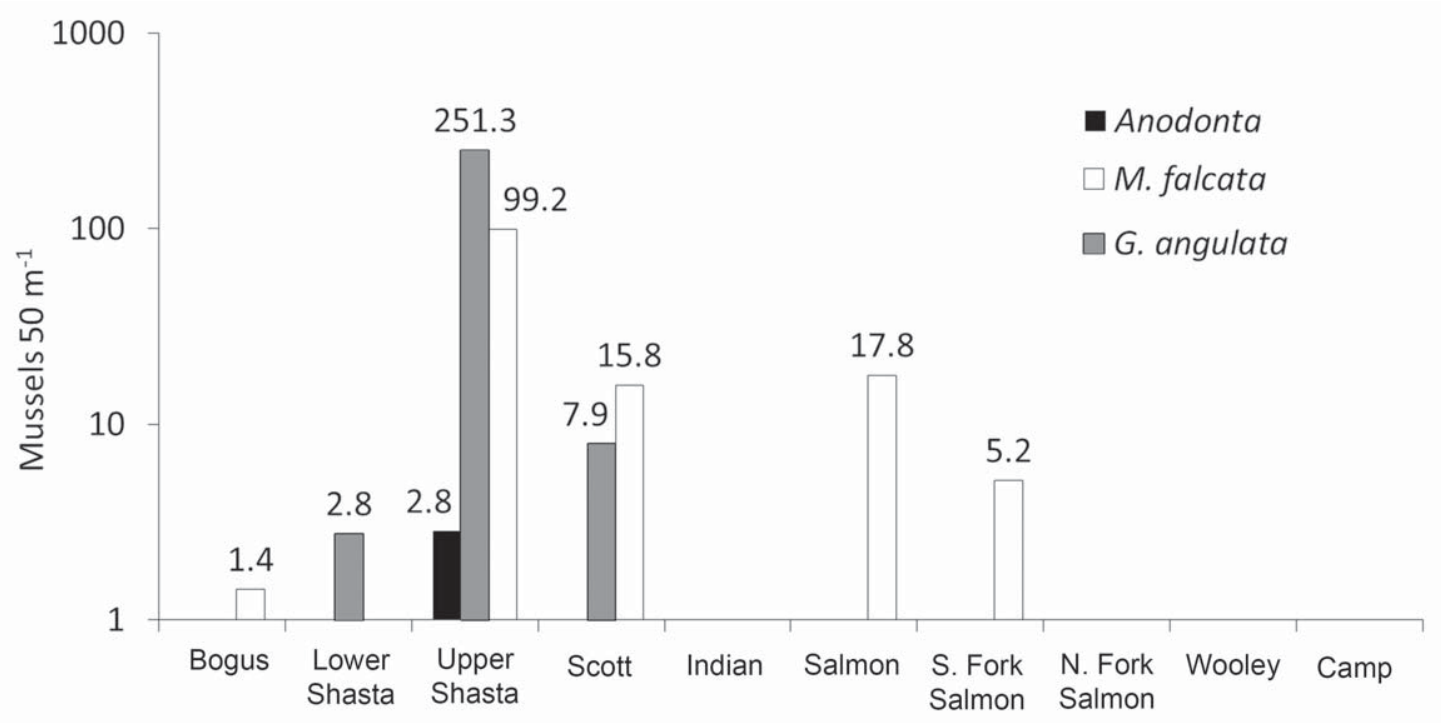

Figure 4. Mussel counts (mussels per $50 \mathrm{~m}$ of tributary channel) within mid Klamath tributaries. Note that the y-axis is a logarithmic scale.

We observed lower abundances of mussels in the tributaries compared to the Klamath mainstem, with the exception of the upper Shasta River, where counts per $50 \mathrm{~m}$ were similar to some mainstem sites (Figure 4). The Shasta River was also the only tributary with all three western mussel genera (Figure 4). For the four gauged tributaries, there was no statistically significant relationship between mussel counts and hydrological variability $\left(C_{v}: \mathrm{r}^{2}\right.$ $=0.35, F=1.06, \mathrm{df}=1,2, P=0.412$; High-Low: $\left.\mathrm{r}^{2}=0.32, F=0.94 \mathrm{df}=1,2, P=0.436\right)$.

\section{Mesohabitat and Microhabitat}

Out of the 82 mainstem survey sites, we sampled 4 steep slope riffles, 17 medium slope riffles, 25 low slope riffles, 35 pools, and 1 run. We excluded the lone run from the GLMMs. We recorded 93 bank edges and 67 bar edges at survey sites. At two sites we failed to record on which side of the channel mussels were located, so those two sites were also excluded from the GLMMs.

We only developed GLMMs for G. angulata abundance. Of the four meso-scale GLMMs we considered, there was strong support for the model that included bank type, channel unit type, and the interaction between channel unit type and bank type as fixed effects (Table 4). Of the 17
TABLE 4. Summary of small sample size Akaike information criterion ( $\mathrm{AIC}_{c}$ ) ranking of $G$. angulata meso-scale abundance GLMMs for data collected from sites in all three years $(\mathrm{n}=79$ sites, $\mathrm{n}=$ 158 observations). Channel $=$ channel unit type; Bank $=$ bank type; $*=$ interaction term. $\Delta_{i}=$ $\mathrm{AIC}_{c}$ of model $_{i}-\mathrm{AIC}_{\mathrm{c}} \mathrm{min} ; \mathrm{k}=$ number of model parameters; $w_{i}=\mathrm{AIC}_{\mathrm{c}}$ weight for model ${ }_{i}$. $\mathrm{AIC}_{\mathrm{c}}$ weights sum to one for the set of models under consideration.

\begin{tabular}{ccccccc}
\hline & \multicolumn{5}{c}{ Channel* $^{*}$} \\
Rank & Channel & Bank & Bank & $\Delta_{i}$ & $\mathrm{k}$ & $w$ \\
\hline 1 & $\mathrm{x}$ & $\mathrm{x}$ & $\mathrm{x}$ & 0.0 & 10 & 0.996 \\
2 & $\mathrm{x}$ & $\mathrm{x}$ & & 10.9 & 7 & 0.004 \\
3 & & $\mathrm{x}$ & & 16.0 & 4 & 0.000 \\
4 & $\mathrm{x}$ & & & 61.2 & 6 & 0.000 \\
\hline
\end{tabular}

micro-scale GLMMs we considered, there was strong support for the model that included bank type, substrate, and flow refuge presence/absence as fixed effects (Table 5).

Information on how $G$. angulata abundance varies among the levels of each fixed effect is provided by figures and the parameter coefficients (and associated confidence intervals) for the top ranked models. G. angulata abundance was not significantly different among the channel unit types (Figure 5a; Table 6). We found significantly 
more G. angulata on bank edges than bar edges (Figure 5b; Table 6, 7). Controlling for availability of substrates, G. angulata were found more frequently in sand than any other substrate, and second-most frequently in gravel; abundances were much lower in all other substrates (Figure $5 c$; Table 7). Controlling for availability of flow refuges, significantly more $G$. angulata were found in flow refuges than outside of flow refuges
(Figure 5d; Table 7). These results corroborated our qualitative observation that most mussels appeared positioned in microhabitats protected from the main current. Within these velocity refuges, mussels would often be embedded in sand or gravel that had settled behind boulders or in bedrock crevices. We rarely found mussels in the thalweg (lowest portion of the river channel) or more than two to three meters from the bank.

TABLE 5. Summary of small-sample size Akaike information criterion ( $\mathrm{AIC}_{\mathrm{c}}$ ) ranking of G. angulata micro-scale abundance GLMMs for data collected from sites in 2010 ( $n=21$ sites, $n=504$ observations). Channel = channel unit type; Bank $=$ bank type $; \mathrm{Sub}=$ substrate type $;$ Flow $=$ flow refuge presence/absence; $*$ interaction term. $\Delta_{i}=\mathrm{AIC}_{\mathrm{c}}$ of model $-\mathrm{AIC}_{\mathrm{c}} \mathrm{min} ; \mathrm{k}=$ number of model parameters; $w_{i}=\mathrm{AIC}_{\mathrm{c}}$ weight for $\operatorname{model}_{i}$. $\mathrm{AIC}_{\mathrm{c}}$ weights sum to one for the set of models under consideration. Only the six highest ranked models out of 17 total models are shown.

\begin{tabular}{|c|c|c|c|c|c|c|c|c|c|c|}
\hline Rank & Channel & Bank & Sub & Flow & Sub*Flow & Channel*Bank & Bank*Flow & $\Delta_{i}$ & $\mathrm{k}$ & $w_{i}$ \\
\hline 1 & & $\mathrm{x}$ & $\mathrm{x}$ & $\mathrm{x}$ & & & & 0.0 & 11 & 0.579 \\
\hline 2 & $\mathrm{x}$ & $\mathrm{x}$ & $\mathrm{x}$ & $\mathrm{x}$ & $\mathrm{x}$ & & & 3.3 & 18 & 0.113 \\
\hline 3 & $\mathrm{x}$ & $\mathrm{x}$ & $\mathrm{x}$ & $\mathrm{x}$ & & $\mathrm{x}$ & & 3.4 & 15 & 0.103 \\
\hline 4 & $\mathrm{x}$ & $\mathrm{x}$ & $\mathrm{x}$ & $\mathrm{x}$ & $\mathrm{x}$ & $\mathrm{x}$ & $\mathrm{x}$ & 4.1 & 21 & 0.075 \\
\hline 5 & $\mathrm{x}$ & $\mathrm{x}$ & $\mathrm{x}$ & $\mathrm{x}$ & & & & 4.2 & 13 & 0.071 \\
\hline 6 & $\mathrm{x}$ & $\mathrm{x}$ & $\mathrm{x}$ & $\mathrm{x}$ & & & $\mathrm{x}$ & 4.5 & 14 & 0.060 \\
\hline
\end{tabular}

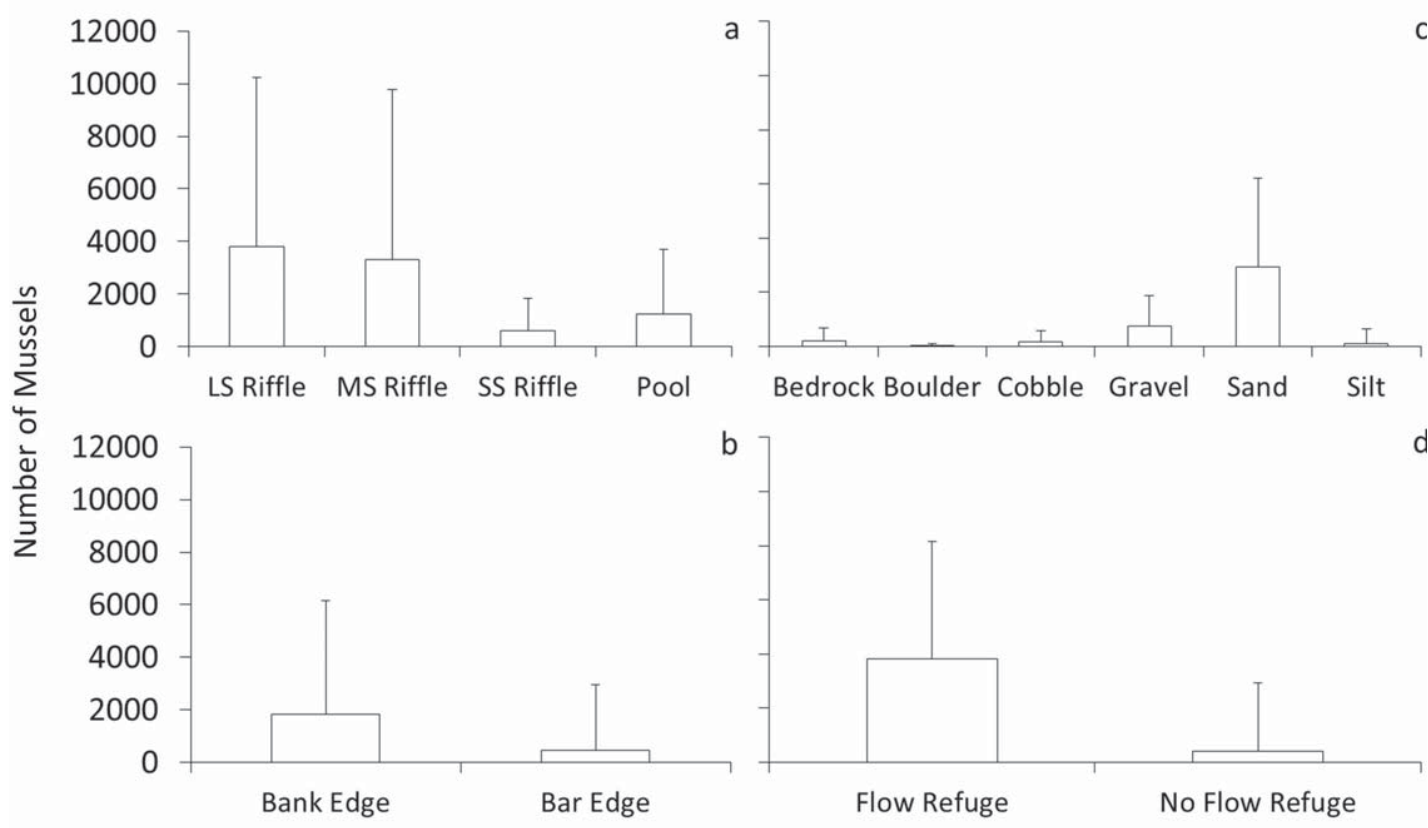

Figure 5. Mean (+SD) mainstem Klamath G. angulata abundance for meso- and micro-scale habitat categories. (a) Total site abundance in different channel unit types from sites sampled in all years. (b) Side of site (the left or right half of a 50 $\mathrm{m}$ section of channel) abundance in different bank types from sites sampled in all years. (c) Total site abundance in different substrate types from sites sampled in 2010. (d) Total site abundance associated with and without potential flow refuges from sites sampled in 2010. 
TABLE 6. Model summary for the $\mathrm{AIC}_{\mathrm{c}}$ top-ranked G. angulata meso-scale model. For each categorical fixed effect, one level is set as the reference level for that effect (the intercept). Fixed effect parameter coefficient estimates are thus the difference between the mussel abundance of the reference level and the level in question (in $\log$ space). Wald $Z$ scores and $P$ values indicate whether a parameter coefficient is different from zero.

\begin{tabular}{lcccc}
\hline Coefficient & Estimate & $\mathrm{SE}$ & $Z$ & $P$ \\
\hline (Intercept) & 8.094 & 0.734 & 11.03 & $<0.0001$ \\
Pool & -1.352 & 0.850 & -1.59 & 0.11 \\
LSriffle & -0.547 & 0.891 & -0.61 & 0.54 \\
SSriffle & -1.736 & 1.659 & -1.05 & 0.30 \\
Bar & -7.388 & 1.146 & -6.45 & $<0.0001$ \\
Pool*bar & 0.765 & 1.304 & 0.59 & 0.56 \\
LSriffle*bar & 6.735 & 1.388 & 4.85 & $<0.0001$ \\
SSriffle*bar & -0.303 & 2.646 & -0.11 & 0.91 \\
\hline
\end{tabular}

\section{Discussion}

\section{Landscape-scale Patterns of Distribution and Abundance}

We found distinct, large-scale patterns of mussel species distribution in the Klamath. Within the mainstem mid Klamath, we observed Anodonta $s p$. occurring only in the furthest upriver survey sites, G. angulata almost throughout, frequently in high numbers, and $M$. falcata only present in high numbers downstream of the confluence with the Salmon River. The unusual "upside-down" nature of the Klamath watershed (NRC 2004, VanderKooi et al. 2011), specifically with regard to hydrological variability, may be responsible for some of the longitudinal variation in mussel distribution we observed. Hydrological variability has been shown to affect mussel distribution, abundance, and community composition in other watersheds, with distinct differences between rivers with different hydrological regimes (diMaio and Corkum 1995, McRae et al. 2004).

We observed an overall decline in mean mussel abundance per site as hydrological variability increased progressing downstream. High values for measures of hydrological variability mean an increase in the magnitude and frequency of high flows and extreme variations from the mean flow,
TABLE 7. Model summary for the $\mathrm{AIC}_{\mathrm{c}}$ top-ranked G. an gulata micro-scale model. For each categorical fixed effect, one level is set as the reference level for that effect (the intercept). Fixed effect parameter coefficient estimates are thus the difference between the mussel abundance of the reference level and the level in question (in log space). Wald $Z$ scores and $P$ values indicate whether a parameter coefficient is different from zero.

\begin{tabular}{lcccc}
\hline Coefficients & Estimate & SE & $Z$ & $P$ \\
\hline (Intercept) & -0.220 & 0.908 & -0.24 & 0.809 \\
Bar & -6.829 & 0.718 & -9.51 & $<0.0001$ \\
Flow refuge & 3.379 & 0.427 & 7.92 & $<0.0001$ \\
Boulder & -3.853 & 0.936 & -4.12 & $<0.0001$ \\
Cobble & 0.027 & 0.760 & 0.03 & 0.972 \\
Gravel & 1.630 & 0.729 & 2.24 & 0.025 \\
Sand & 3.827 & 0.756 & 5.07 & $<0.0001$ \\
Silt & -1.544 & 0.898 & -1.72 & 0.085 \\
Sub cover & 9.855 & 2.491 & 3.96 & $<0.0001$ \\
\hline
\end{tabular}

which mean an increased probability of riverbed scouring and/or high shear stresses that may prevent mussel recruitment. High shear stress is associated with low substrate stability and increased energy required by the mussel to maintain its position and feed (Rempel et al. 2000). Large variability in flows also reduces the proportion of the channel that is suitable for mussels during both high and low flow periods. Habitats suitable for mussels during peak flows (e.g., edge habitats) are dry during low flow periods and habitats suitable during low flow periods (e.g., the central channel) experience high shear stress and bedload transport during peak flows. Hence, the further downstream a site was located within our study area, the lower the probability that it would support mussel recruitment and persistence under a range of annual hydrological conditions.

The pattern of species distribution throughout the system may also be partially a function of hydrological variability. Research has shown that shell morphology, shell thickness, and other species-specific adaptations enable mussels to tolerate varying hydrological and substrate stability conditions (Stanley 1981, Allen and Vaughn 2009, Hornbach et al. 2010), and such adaptations may contribute to the observed pattern of species distributions in the Klamath. Anodonta is a soft- 
substrate genus (Nedeau et al. 2009) with a thin shell, meaning that it has little ballast in fast currents and cannot withstand scouring. This could explain its relatively high abundance in the hydrologically regulated stretch of river just below Irongate Dam, which maintains a stable flow year-round (Williams and Curry 2011). As hydrological variability increases (and the availability of stable substrate presumably decreases) further downstream from Irongate, Anodonta disappear. G. angulata and $M$. falcata are more common in downstream areas, probably due to thicker shells which allow them to withstand scouring in high flow events (Burch 1973, COSEWIC 2003). We observed that $G$. angulata and $M$. falcata are also better able to wedge themselves tightly into substrate.

The pattern we observed in the Klamath is different from patterns of longitudinal distributions of mussel species found in the few published studies of mussels in other western rivers. $M$. falcata occurred in relatively higher numbers in the headwaters of the North and Middle Fork John Day, while G. angulata and Anodonta sp. were more common at downstream sites in this system; in the Umatilla system, both Anodonta $s p$. and $G$. angulata were collected only from the furthest downstream sites sampled (Brim Box et al. 2006). Howard and Cuffey (2003) observed a similar pattern in the upper South Fork Eel River drainage of California's North Coast range, with M. falcata occurring throughout the study area of the upper drainage, but aggregations of Anodonta $s p$. only occurring at the downriver end of the surveyed reach. Both the John Day/Umatilla and Eel systems have a more commonly observed watershed structure compared to the Klamath: steep mountain headwaters transitioning to low-relief mainstems. These differences in basin structure may contribute to the differences with the Klamath in how mussel species are distributed throughout the basins.

Although hydrological variability is one important factor constraining mussel distribution at the macro scale, it does not account for all the variation within and among species distributions, nor do the other physical habitat factors described in this study. To explain more of the variation in mussel distribution, it may be necessary to consider additional variables and move to a functional rather than strictly physical view of mussel habitat. Such a "functional habitat" approach asks, "What does a mussel need from its habitat?" (Strayer 2008). For example, a combination of biotic and abiotic factors important to mussels includes stable habitat and protection from sediment transport; sufficient food; dispersal opportunity (via host fish availability); water chemistry; temperature; and protection from predators (Newton et al. 2008). Therefore, physical habitat variables such as substrate and hydraulics should be not be analyzed as the sole predictive variables, because they can only partially explain mussel distributions (Allen and Vaughn 2010). Other factors that could be influential in watershed-scale distribution of mussels which we did not measure include water quality (McRae et al. 2004), stream productivity/food availability (Brim Box et al. 2006), water temperature, host fish abundance/distribution (Vaughn and Taylor 2000), surrounding land use (Arbuckle and Downing 2002), and river aggradation (Vannote and Minshall 1982).

We observed all three western mussel genera in the major tributaries of the mid Klamath (although only a single tributary hosted all three together), but we were unable to identify clear patterns among tributaries due to the patchy nature of our tributary sampling and the inherent difficulties of making cross-basin comparisons without accounting for differences in geology and watershed size, as well as drastic anthropogenic alterations to basin hydrology in the Scott and Shasta watersheds. However, a few observations stood out from our surveys. Mussel abundance (standardized as counts per $50 \mathrm{~m}$ to be comparable with mainstem counts) was generally lower in tributaries and distribution was quite restricted as compared to the mainstem Klamath. The Shasta, with the lowest measures of hydrological variability of the four gauged tributaries, was the only tributary with all three western genera, and by far the highest counts of mussels, approaching abundances of some sites on the mainstem. The majority of the mussels we found in the Shasta were located at sites near its low-gradient, spring-fed, and hydrologically stable headwaters. Similarly, the low-gradient reach near 
the confluence of the Salmon with the Klamath and the low-gradient reaches of the South Fork of the Salmon had relatively high densities of mussels, although not approaching those of the Shasta. Some tributaries such as Wooley Creek and Indian Creek had no mussels at all, and these had hydrologically unstable, high-gradient profiles. Scour during high flow events in the steep canyon reaches of these streams probably limits recruitment and long-term survival of mussels.

\section{Mesohabitat Factors}

Many researchers attempting to explain patterns of mussel abundance and distribution agree that shear stress, substrate stability, and flow refuges are three important meso- and micro-scale determinants limiting mussel recruitment and survival (Vannote and Minshall 1982, Strayer 1999, Morales et al. 2006).

Previous studies (Vannote and Minshall 1982, Howard and Cuffey 2003, Gangloff and Feminella 2007) found that channel unit type (i.e., whether a reach is a riffle, run, pool, etc.), influences mussel abundance, though the studies differed about which channel unit type was "best" for mussel habitat. Our best model of meso-scale mussel abundance included channel unit type as a predictor variable, though there was a high degree of variation in mussel counts among sites with the same channel unit type-indicating that additional variables are important at this scale of observation. Channel unit type was not an important predictor of mussel abundance at the micro scale when micro-scale habitat variables were included in a model, suggesting that channel unit types do not account for important fine scale habitat variation.

It may be that suitability of habitat types and the degree to which a physical habitat component influences mussel abundance differs from river to river depending on hydrological and geological conditions. If so, this underscores the importance of understanding watershed-level controls-hydrological variability, gradient and geology — on the abundance and distribution of particular mussel species. It also underscores the need to move to a "functional habitat" approach incorporating biotic and abiotic factors important to mussel life stages.
The habitat survey we selected our sites from used several criteria to define channel unit types. A functional habitat approach might identify the particular factors relevant to mussels (e.g., channel gradient) rather than using broad categories that incorporate multiple physical habitat variables, some of which may not be not be relevant to mussels. We suggest that future studies in the Klamath take a functional habitat approach.

In contrast to channel unit type, bank type-another meso-scale characteristic - was an important predictor of G. angulata abundance at both meso and micro scales. Mussels were significantly more abundant on bank edges than on bar edges. Bank type is indicative of the shear stress experienced by and substrate stability of edge habitats at scouring flows. Above a certain level of shear stress, mussels are dislodged or crushed/scoured by large mobile substrate (Strayer 1999). The loose cobbles and gravels that compose bar edges move during flood flows, while the boulders, bedrock, and other hard features that compose bank edges remain stable, with less sediment deposition, providing habitats where mussels can recruit and persist over the long term. Bank type is thus likely indicative of the availability of flow refuges, an important micro scale habitat variable.

The top-ranked meso-scale model also included the interaction between channel unit type and bank type. The importance of this interaction is not surprising: channel edges vary in their suitability as habitat depending on factors such as gradient, which is included in channel unit type. Thus, overall banks are more suitable than bars for mussel habitat, but vary in suitability depending on association with channel unit type.

\section{Microhabitat Factors}

Considerable debate and uncertainty remains regarding the strength of associations between sediments and mussels (Brim Box and Mossa 1999). More sediment particle size categories than the ones used in this study may be necessary to accurately describe habitat associations (Brim Box and Mossa 1999). Interpreting the results of mussel substrate distribution on their own can be difficult; however, if substrate size is considered 
in conjunction with information on the hydraulic environment, the results may be more valuable (Allen and Vaughn 2010).

We found $G$. angulata more frequently in sand than all other substrates, and second-most frequently in gravel. Substrate size is a commonly reported habitat characteristic for studies of mussel distribution; however, substrate often fails to be a strong predictive variable (Strayer and Ralley 1993), especially in comparisons across drainages. Microhabitat factors such as substrate size may not themselves control mussel distribution; rather, they likely serve as a visible proxy for the real controls, hydraulics and substrate stability.

At the micro scale mussels tended to inhabit "flow refuges," where long-term substrate stability is ensured by protective features like boulders and low-velocity regions on edges of islands (Morales et al. 2006). After accounting for the availability of potential flow refuges, we found significantly more mussels associated with flow refuges than with those microhabitats lacking flow refuges. It is important to note that in contrast to Strayer's (1999) study of flow refuges, we did not actually map flow refuges during high flow events. We noted physical features which appeared likely to alter the flow of water over the riverbed. These physical features, such as boulders or bedrock ledges, often accumulate finer sediments, mostly sand or gravel, in the micro eddies on their lee sides. Mussels situated in flow refuges are protected from scouring flows and have substrate of a grain size small enough in which to embed themselves. Our results suggest that the association of mussels with specific sediment size classes and the distribution of mussels in relation to flow refuges are directly linked. This supports Vannote and Minshall (1982), Strayer (1999), and Gangloff and Feminella's (2007) conclusions that mussel abundance at the reach and micro-scale levels is low in areas of high shear stress and is controlled by availability of flow refuges.

\section{Summary}

Our study, examining mussel distribution and abundance in the middle Klamath basin at three nested spatial scales, demonstrates the need for a multi-scale approach when examining mussel habitat associations. We showed that distribution patterns can be partially explained by different physical variables at different scales. The patterns observed at each scale suggest a common influence of hydraulics as a major driver of mussel distribution. Hydrological variability, which changes longitudinally across the middle Klamath basin, limits the amount of the channel that is potentially suitable habitat. Hydraulics and hydrological variability are linked: part of a watershed with variable hydrological conditions (extreme high and low flows, high frequency of high flows) is likely to have small-scale hydraulic conditions (shear stress, scour) that are often unfavorable for mussels. At meso and micro scales, mussels are found predominantly along bank edges, which provide stable substrates, and in flow refuges where fine sediments accumulate. Further research that measures flow refuges, substrate stability and complex hydraulic variables during periods of high flow would likely corroborate our results by taking a direct rather than indirect look at these important variables. Additionally, future research should incorporate biotic, chemical, and anthropogenic variables such as land use to achieve a true functional habitat perspective.

\section{Acknowledgements}

We are grateful for the assistance of many people without whom this project would not have been possible. David Wolf, Dr. Jayne Brim Box, Christine O'Brien, and Donna Nez of the Confederated Tribes of the Umatilla Indian Reservation provided expertise in research design, as well as assistance in the field. Funding was provided from a U.S. Fish and Wildlife Service Tribal Wildlife Grant (\#W-8-09-023) and from Whitman College. The Mid Klamath Watershed Council, LeRoy Cyr of the U.S. Forest Service, and the Salmon River Restoration Council provided field gear and local knowledge of the river. Thanks to Sam Stroich for support on all levels of the project. Our field technicians included Marie Westover, Michelle Krall, Kenneth Brink, Jamie Muldoon, Alex Corum, J. 
J. Reed, Wind Beaver, and Kate Ceronsky. Dr. Loveday Conquest provided help with statistical analysis and Dr. Daniel Schindler reviewed the manuscript. Comments from anonymous reviewers helped improve the manuscript. We also thank the

\section{Literature Cited}

Allen, D. C., and C. C. Vaughn. 2009. Burrowing behavior of freshwater mussels in experimentally manipulated communities. Journal of the North American Benthological Society 28:93-100.

Allen, D. C., and C. C. Vaughn. 2010. Complex hydraulic and substrate variables limit freshwater mussel species richness and abundance. Journal of the North American Benthological Society 29:383-394.

Anderson, D. R., and K. P. Burnham. 2002. Avoiding pitfalls when using information-theoretic methods. Journal of Wildlife Management 66:912-918.

Anderson, D. R., K. P. Burnham, and W. L. Thompson. 2000. Null hypothesis testing: problems, prevalence, and an alternative. Journal of Wildlife Management 64:912-923.

Arbuckle, K. E., and J. A. Downing. 2002. Freshwater mussel abundance and species richness: GIS relationships with watershed land use and geology. Canadian Journal of Fisheries and Aquatic Sciences 59:310-316

Asarian, E., J. Kann, and W. Walker. 2010. Klamath River nutrient loading and retention dynamics in free-flowing reaches, 2005-2008. Final Technical Report to the Yurok Tribe Environmental Program. Yurok Tribe, Klamath, California.

Beechie, T. J., M. Liermann, E. M. Beamer, and R. Henderson. 2005. A classification of habitat types in a large river and their use by juvenile salmonids. Transactions of the American Fisheries Society 134:717-729.

Bolker, B. M., M. E. Brooks, C. J. Clark, S. W. Geange, J. R. Poulsen, M. H. H. Stevens, and J. S. White. 2009. Generalized linear mixed models: a practical guide for ecology and evolution. Trends in Ecology and Evolution 24:127-135.

Brim Box, J., J. Howard, D. Wolf, C. O'Brien, D. Nez, and D. Close. 2006. Freshwater mussels (Bivalvia: Unionoida) of the Umatilla and Middle Fork John Day Rivers in Eastern Oregon. Northwest Science 80:95-107.

Brim Box, J., and J. Mossa. 1999. Sediment, land use, and freshwater mussels: prospects and problems. Journal of the North American Benthological Society 18:99-117.

Burch, J. B. 1973. Freshwater Unionacean Clams (Mollusca: Pelecypoda) of North America. Biota of Freshwater Ecosystems Identification Manual No. residents of Orleans, Somes Bar, Forks of Salmon, and Sawyers Bar who welcomed us into their communities while supporting and encouraging the project. Yootva!

11. U.S. Environmental Protection Agency, Washington, D.C.

Chong, J. P., J. C. Brim Box, J. K. Howard, D. Wolf, T. L. Myers, and K. E. Mock. 2008. Three deeply divided lineages of the freshwater mussel genus Anodonta in western North America. Conservation Genetics 9:1303-1309.

[COSEWIC] Committee on the Status of Endangered Wildlife in Candada. 2003. COSEWIC Assessment and Status Report on the Rocky Mountain Ridged Mussel (Gonidea angulata) in Canada. Committee on the Status of Endangered Wildlife in Canada. Ottawa.

diMaio, J., and L. D. Corkum. 1995. Relationship between the spatial distribution of freshwater mussels (Bivalvia: Unionoida) and the hydrological variability of rivers. Canadian Journal of Zoology 73:663-671.

Driver, H. E. 1939. Culture element distributions: X: Northwest California. Anthropological Records 1:297-433.

Ferrara, J., editor. 2004. Ananakupheekxunnikich: Karuk ethnographic notes as spoken principally by Phoebe Maddux, and heard and written in the years 19261929 by J. P. Harrington. Karuk Tribe of California: Happy Camp.

Gangloff, M. M., and J. W. Feminella. 2007. Stream channel geomorphology influences mussel abundance in southern Appalachian streams, U.S.A. Freshwater Biology 52:64-74.

Gibbs, G. 1860. Journal of the expedition of colonel Redick M'kee, United States Indian agent, through northwestern California. Performed in the summer and fall of 1851. Archives of Aboriginal Knowledge 3:99-177.

Greengo, R. E. 1952. Shellfish foods of the California Indians. Kroeber Anthropological Society Papers 7:63-114.

Hawkins, C.P., J. L. Kershner, P. A. Bisson, M. D. Bryant, L. M. Decker, S. V. Gregory, D. A. Mccullough, C. K. Overton, G. H. Reeves, R. J. Steedman, and M. K. Young. 1993. A hierarchical approach to classifying stream habitat features. Fisheries 18:3-12.

Hendrix, N., S. Campbell, M. Hampton, T. Hardy, C. Huntington, S. Lindley, R. Perry, T. Shaw, and S. Williamson. 2011. Fall Chinook salmon life cycle production model report to expert panel. Draft report. Prepared by R2 Natural Consultants, U. S. Geological Survey, U. S. Fish and Wildlife Service, Clearwater Biostudies, Texas State University, and 
NOAA Fisheries for the expert panel reviewing Chinook salmon of the Klamath River Basin.

Hillemeier, D., T. Soto, S. Silloway, A. Corum, M. Kleeman, and L. Lestelle. 2009. The role of the Klamath River mainstem corridor in the life history and performance of juvenile coho salmon (Oncorhynchus kisutch). Final report. Prepared by the Karuk Tribe Department of Natural Resources, Yurok Fisheries Program, and Biostream Environmental for the U.S. Bureau of Reclamation, Mid-Pacific Region, Klamath Area Office, Klamath Falls.

Hornbach, D. J., V. J. Kurth, and M. C. Hove. 2010. Variation in Freshwater Mussel Shell Sculpture and Shape Along a River Gradient. American Midland Naturalist 164:22-36.

Howard, J. K., and K. M. Cuffey. 2003. Freshwater mussels in a California north coast range river: occurrence, distribution and controls. Journal of the North American Benthological Society 20:63-77.

Howard, J. K., and K. M. Cuffey. 2006. The functional role of native freshwater mussels in the fluvial benthic environment. Freshwater Biology 51:460-474.

Howard, J. K. 2010. Sensitive freshwater mussel surveys in the Pacific Southwest region: an assessment of conservation status. Final report. Prepared by the Nature Conservancy for USDA Forest Service Pacific Southwest Region Regional Office, Vallejo.

Jowett, I. G., and M. J. Duncan. 1990. Flow variability in New Zealand rivers and its relationship to in-stream habitat and biota. New Zealand Journal of Marine and Freshwater Research 24:305-317.

Kann, J. 2006. Microcystis aeruginosa occurrence in the Klamath River System of Southern Oregon and Northern California. Technical memorandum prepared for the Yurok Tribe Environmental and Fisheries Programs. Aquatic Ecosystem Sciences LLC, Ashland.

Karuk Tribe. 2008. Water Quality Assessment Report 2008. Karuk Tribe Department of Natural Resources, Orleans.

Kroeber, A. L., and S. A. Barrett. 1960. Fishing among the Indians of northwestern California. University of California Press, Berkeley.

Lessells, C. M., and P. T. Boag. 1987. Unrepeatable repeatabilities: a common mistake. The Auk 104:116-121.

Mock, K. E., J. C. Brim Box, J. P. Chong, J. K. Howard, D. A. Nez, D. Wolf, and R. S. Gardner. 2010. Genetic structuring in the freshwater mussel Anodonta corresponds with major hydrologic basins in the western United States. Molecular Ecology 19:569-591.

McRae, S. E., J. D. Allan, and J. B. Burch. 2004. Reachand catchment-scale determinants of the distribution of freshwater mussels (Bivalvia: Unionidae) in south-eastern Michigan, U.S.A. Freshwater Biology 49:127-142.

Morales, Y., L. J. Weber, A. E. Mynett, and T. J. Newton. 2006. Effects of substrate and hydrodynamic conditions on the formation of mussel beds in a large river. Journal of the North American Benthological Society 25:664-676.

[NRC] National Research Council. 2004. Endangered and threatened fishes in the Klamath River Basin: causes of decline and strategies for recovery. The National Academies Press, Washington, DC.

Nedeau, E., A. K. Smith, J. Stone, and S. Jepsen. 2009. Freshwater Mussels of the Pacific Northwest, $2^{\text {nd }}$ Edition. The Xerces Society, Portland.

Neves, R. J., A. E. Bogan, J. D. Williams, S. A. Ahlstedt, and P. W. Hartfield. 1997. Status of aquatic mollusks in the southeastern United States: a downward spiral of diversity. In Benz, G. W., and D. E. Collins (editors). Aquatic fauna in peril: the southeastern perspective. Special publications 1, Southeast Aquatic Research Institute. Lenz Design and Communications, Decatur. Pp. 44-86.

Newton, T. J., D. A. Woolnough, and D. L. Strayer. 2008. Using landscape ecology to understand and manage freshwater mussel populations. Journal of the North American Benthological Society 27:424-439.

Parmalee, P. W., and W. E. Klippel. 1974. Freshwater mussels as a prehistoric food resource. American Antiquity 39:42-434.

R Development Core Team. 2011. R: A language and environment for statistical computing. R Foundation for Statistical Computing, Vienna, Austria. ISBN 3-900051-07-0, URL http://www.R-project.org/.

Rempel, L. L., J. S. Richardson, and M. C. Healey. 2000. Macroinvertebrate community structure along gradients of hydraulic and sedimentary conditions in a large gravel-bed river. Freshwater Biology 45:57-73.

Skaug, H., D. Fournier, A. Nielsen, A. Magnusson, and B. Bolker. 2012. glmmADMB: generalized linear mixed models using AD Model Builder. R package version 0.7.2.12.

Stanley, S. M. 1981. Infaunal Survival: Alternative Functions of Shell Ornamentation in the Bivalvia (Mollusca). Paleobiology 7:384-393.

Strayer, D. L., and J. Ralley. 1993. Microhabitat use by an assemblage of stream-dwelling unionaceans (Bivalvia), including two rare species of Alasmidonta. Journal of the North American Benthological Society 12:247-258.

Strayer, D. L. 1999. Use of flow refuges by unionid mussels in rivers. Journal of the North American Benthological Society 18:468-476.

Strayer, D. L. 2008. Freshwater Mussel Ecology: A Multifactor Approach to Distribution and Abundance. University of California Press, Berkeley, California.

Strayer, D. L., and D. R. Smith. 2003. A guide to sampling freshwater mussel populations. American Fisheries Society Monograph 8. American Fisheries Society, Bethesda.

USDA Forest Service. 2004. Database of the freshwater mollusks of the western United States [Excel 
file]. Unpublished data on file at Rocky Mountain Research Station, Logan, UT.

United States Fish and Wildlife Service. 2002. Mesohabitat typing on mainstem Klamath River from Iron Gate Dam to Weitchepec. Unpublished data on file at United States Fish and Wildlife Service Office, Arcata, CA.

United States Geological Survey. 2011. USGS real-time water data for California. Available online at http:// waterdata.usgs.gov/ca/nwis/rt (accessed 5/26/2011).

VanderKooi, S., L. Thorsteinson, and M. Clark. 2011. Environmental and historical setting. In Thorsteinson, L., S. VanderKooi, and W. Duffy (editors). Proceedings of the Klamath Basin Science Conference, Medford, Oregon, February 1-5, 2010. U. S. Geological Survey Open-File Report 2011-1196. Pp. 31-36.

Vannote, R. L., and G. W. Minshall. 1982. Fluvial processes and local lithology controlling abundance, structure, and composition of mussel beds. Proceedings of the National Academy of Sciences of the United States of America 79:4103-4107.

Vaughn C. C., K. B. Gido, and D. E. Spooner. 2004. Ecosystem processes performed by unionid mussels

Received 4 September 2012

Accepted for publication 20 March 2013 in stream mesocosms: species roles and effects of abundance. Hydrobiologia 527:35-47.

Vaughn C. C., and C. C. Hakenkamp. 2001. The functional role of burrowing bivalves in freshwater ecosystems. Freshwater Biology 46:1431-1446.

Vaughn, C. C., and C. M. Taylor. 2000. Macroecology of a host-parasite relationship. Ecography 23:11-20.

Williams J., and D. Curry. Watershed characterization. In Thorsteinson, L., S. VanderKooi, and W. Duffy (editors). Proceedings of the Klamath Basin Science Conference, Medford, Oregon, February 1-5, 2010. U. S. Geological Survey Open-File Report 2011-1196. Pp. 37-74.

Williams, J. D., M. L. Warren Jr., K. S. Cummings, J. L. Harris, and R. J. Neves. 1993. Conservation status of freshwater mussels of the United States and Canada. Fisheries 18:5-22.

Zigler, S. J., T. J. Newton, J. J. Steuer, M. R. Bartsch, and J. S. Sauer. 2008. Importance of physical and hydraulic characteristics to unionid mussels: a retrospective analysis in a reach of large river. Hydrobiologia 598:343-360. 